\title{
Seasonal Formation of Tree Rings in Siberian Larch and Scots Pine in the Southern Taiga of Central Siberia
}

\author{
E. V. Kalinina ${ }^{a}$, A. A. Knorre ${ }^{a, b}$, M. V. Fonti ${ }^{a, *}$, and E. A. Vaganov ${ }^{a, c}$ \\ ${ }^{a}$ Siberian Federal University, Krasnoyarsk, 660041 Russia \\ ${ }^{b}$ Stolby State Nature Reserve, Krasnoyarsk, 660006 Russia \\ ' Sukachev Institute of Forest, Siberian Branch, Russian Academy of Sciences, Krasnoyarsk, 660036 Russia \\ *e-mail: marina.fonti@mail.ru
}

Received June 14, 2018; revised June 30, 2018; accepted July 9, 2018

\begin{abstract}
A comparative analysis of the seasonal formation of tree rings has been performed in Siberian larch (Larix sibirica Ledeb.) and Scots pine (Pinus sylvestris L.), growing in the southern taiga of Central Siberia in two sites on the altitudinal transect (200 and $536 \mathrm{~m}$ a.s.1.). Core samples were taken from April to September in 2012. The results have shown that the onset and duration of different phases of tree ring formation in larch and pine are determined by the geographic location of the sites and the related temperature gradient. It should be noted that species-specific features of tree growth have an effect on the formation of xylem cells during the growing period and, as a consequence, on the dimensional anatomical parameters of tracheids.
\end{abstract}

Keywords: Larix sibirica, Pinus sylvestris, temperature gradient, xylem, cambial activity, tree radial growth, anatomical parameters of wood

DOI: $10.1134 / \mathrm{S} 1067413619030068$

Projected changes in air temperature and precipitation, as well as expected increase in atmospheric $\mathrm{CO}_{2}$, serve as a basis for expected changes in the composition, structure, and productivity of forest ecosystems [1]. The studies of tree-ring structure and the rate and duration of different phases of xylem formation make it possible to reveal the relationship between environmental changes and radial tree growth, since these parameters reflect the conditions of different intervals of the growing season and differently record environmental changes $[2,3]$. In turn, the structure of the xylem reflects the functional balance between the efficiency of water transport (for reaching the optimal growth), expenditures for the construction of tracheid cell walls (for the optimization and safety of the waterconducting system), and mechanical support of the assimilatory apparatus, as well as between the contents of water and nonstructural carbohydrates (for the resistance to stress factors) $[4,5]$.

The influence of environmental factors on the seasonal growth of coniferous and deciduous woody plant species was studied using different methods in different climatic and natural zones [6-8]. Of greatest interest are studies that consider the duration of the growing season of boreal trees based on analysis of wood formation $[3,6,9]$. This study deals with the seasonal formation of tree rings in Siberian larch (a deciduous coniferous species) and Scots pine (an evergreen coniferous species), growing in the low-mountain and mid-mountain belts of southern taiga, which accounts for different temperature regimes in the study area. The design of studies of sites along altitudinal transects $[10,11]$ is of particular ecological value for interpreting the response of trees to past and predicted climate changes, since it represents a "natural experiment" in which the onset and duration of tree growth vary throughout the season, depending on the position of the studied forests (elevation above sea level) and related air temperatures (up to $0.5^{\circ} \mathrm{C}$ per $100 \mathrm{~m}$ elevation). This design used under conditions of significant climate warming in spring over the past decades, with air temperature being a determinant factor for the onset and duration of the growing period [12] makes it possible to assess probable changes in the growth of main forest-forming tree species that may be caused by climate warming.

This study was performed to assess the effect of air temperature on the time of initiation of the cambial activity of woody plants and on the duration of processes of the extension and thickening of secondary tracheid walls, which, in turn, influences the tree-ring width and anatomical structure. More specific purposes were to evaluate differences in the rate of treering formation between larch and pine in the studied habitats and reveal the main factors determining the seasonal dynamics of ring formation. 


\section{MATERIAL AND METHODS}

Siberian larch (Larix sibirica Ledeb.) and Scots pine (Pinus sylvestris L.) were studied in the Stolby

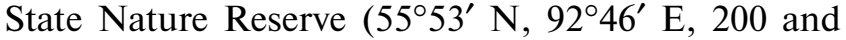
536 above sea level). The climate of the area is extremely continental, the average annual temperature and precipitation are $-0.13^{\circ} \mathrm{C}$ and $660 \mathrm{~mm}$ (the data of Stolby weather station for 1947-2016). The study year (2012) was marked by differences from the average over the entire observation period in higher air temperatures $\left(13.9^{\circ} \mathrm{C}\right.$ vs. $\left.12.0^{\circ} \mathrm{C}\right)$ and lower precipitation (191.4 vs. $369.4 \mathrm{~mm}$ ) during the growing season (May to September).

In 2012, temporary sample plots were established for studying the intra- and interseasonal changes in the processes of xylem formation in coniferous species and assessing the relationship of these processes with seasonal phases of plant growth. The sites were selected according to the principle of relation to permanent phenological sites of the nature reserve and two local weather stations located at Laletino and Narym ranger stations. Laletino site (LAL, $200 \mathrm{~m}$ a.s.l.): LAL-1, pine-birch forb-grass-sedge forest; LAL-2, light coniferous grass-sedge forest. Narym site (NAR, $536 \mathrm{~m}$ a.s.1.), light coniferous-birch tall herb-grasssedge forest. According to the data from local weather stations, precipitation over the growing period in Laletino and Narym sites was 81.4 and $191.4 \mathrm{~mm}$; annual average air temperature was 0.06 and $-0.37^{\circ} \mathrm{C}$; and the soil surface temperature was 4.4 and $3.2^{\circ} \mathrm{C}$, respectively. The soil temperature at a depth of $20 \mathrm{~cm}$ (measurements were carried out only for the Narym site) was $4.0^{\circ} \mathrm{C}$.

We selected four dominant trees of each species (pine and larch) in the NAR site, four pine trees in the LAL-1 site, and four larch trees in the LAL- 2 site. The age of trees was the same for NAR and LAL, being 90 years for pine and 105 years for larch. The height and diameter of trees was $25 \mathrm{~m}$ and $30 \mathrm{~cm}$ for larch and $22 \mathrm{~m}$ and $43 \mathrm{~cm}$ for pine. Wood core samples about $1 \mathrm{~cm}$ long (containing two-three tree rings over the last growth years) were taken from each tree from midApril to mid-September in 2012 using a Hagloff increment borer (Sweden); they were taken in a spiral pattern around the trunk in increments of $5 \mathrm{~cm}$ at a height of $1.3 \mathrm{~m}$ from the soil surface once a week. After being collected, they were immediately placed into test tubes with a glycerol-alcohol-water fixative $(1: 1: 1)$. In total, seasonal wood samples were collected 22 times over the growing period.

Parameters of tree rings being formed were measured on thin wood cross sections that were made using an MS-2 sledge microtome. Sections were placed in 2\% Astra Blue solution and 1\% safranin solution for the contrastive staining of lignified and unlignified tissues. The size of different zones of rings and the number and size of cells were measured using an image analysis system (Carl Zeiss, Jena, Germany) and AxioVision SE64 Rel. 4.9.1 software package, which made it possible to determine the parameters of cell structures in different parts of a tree ring in a semiautomatic regime. Three radial rows of cells (from the internal to external tree-ring boundary) were measured in each tree ring and the values were then averaged.

We used the following scheme to divide cells into zones: (1) cambial zone; (2) cell extension zone; (3) zone of initial cell wall lignification; and (4) mature tracheid zone. The use of a polarization filter made it possible to carry out the detailed division of a developing ring, including differentiation of individual zones of extension and initial lignification.

Parameters of tracheids in a completely formed tree ring of 2012 were measured for the last seasonal sample. Five radial rows of cells with the highest cross section area were selected. The radial lumen diameter (LD) and double cell-wall thickness (2CWT) were measured and then used to calculate the radial size of tracheids $(D=\mathrm{LD}+2 \mathrm{CWT})$. According to Mork's index [13], the ratio between the width of the double cell wall and lumen diameter was used to determine the size of earlywood (EW, 2CWT $<$ LD) and latewood (LW, 2CWT $>$ LD) zones in each ring.

\section{RESULTS}

The cambial zone of the studied trees included four to eight cells during their dormant period (in spring and autumn) (Figs. 1b, 1c, 1e, 1f). In the LAL site (200 $\mathrm{m}$ a.s.l.), the onset of cambial activity towards the xylem beginning from May 12 was simultaneously observed in larch and pine. The sum of air temperatures for 10 days prior to the division of cambial cells was $79.34^{\circ} \mathrm{C}$ and the sum of soil surface temperatures was $38.17^{\circ} \mathrm{C}$ (the data from the local weather station in the LAL site). In the NAR site (536 $\mathrm{m}$ a.s.1.), the cambial activity in larch started on May 18, while that in pine was first observed a week later, when the sums of average air and soil surface temperatures was 64.64 and $46.89^{\circ} \mathrm{C}$, respectively (the data from the local NAR weather station for the period from May 15 to 24).

The cambial activity was observed for 63 days in both species from the NAR site and for 70 and 77 days in larch and pine, respectively, from the LAL site (Table 1). During this period, the average cell number was 9 in the cambial zone for larch trees and 11 for pine trees in each site. The maximum activity of the cambial zones of trees in the NAR site were observed a week earlier (May 25) than in the LAL site (June 2), at the same time first xylem cells in the extension zone appeared (see Figs. 1b, 1c, 1e, 1f). The end of the cambial activity was recorded in late July and coincided with the period of maximum daily air temperatures (up to $22.16^{\circ} \mathrm{C}$ ) (Figs. 1a, 1d). The extension process was completed in July 27 for larch in the Laletino site and in August 3 simultaneously for the other trees in the two sites. 
Air and soil surface temperature, ${ }^{\circ} \mathrm{C}$

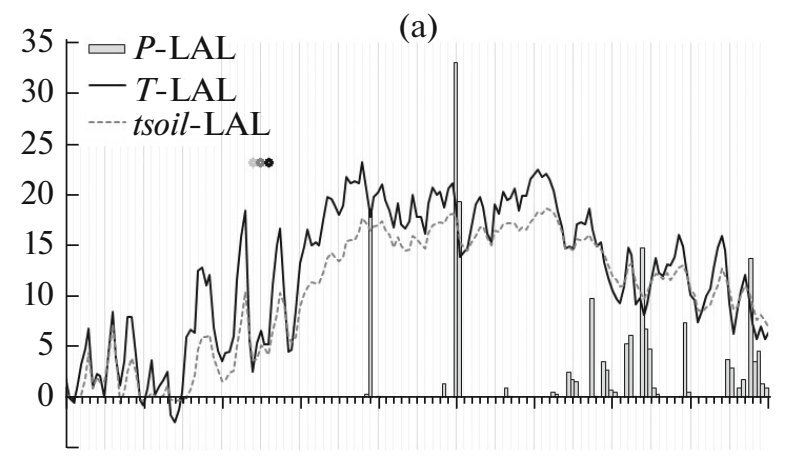

Number of cells

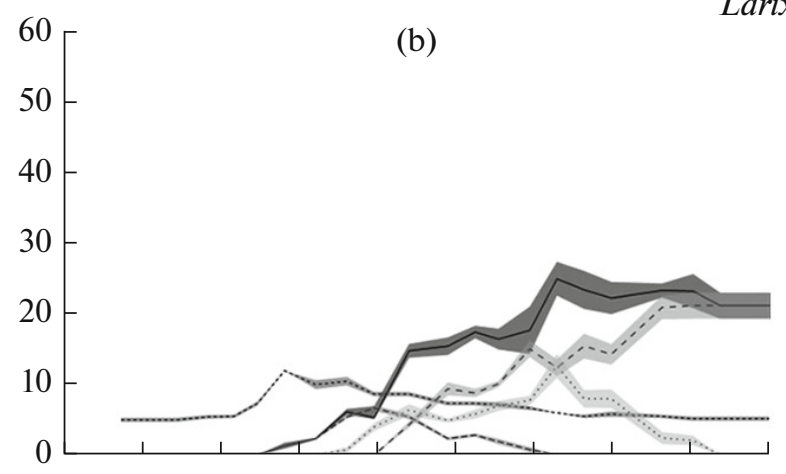

(c)

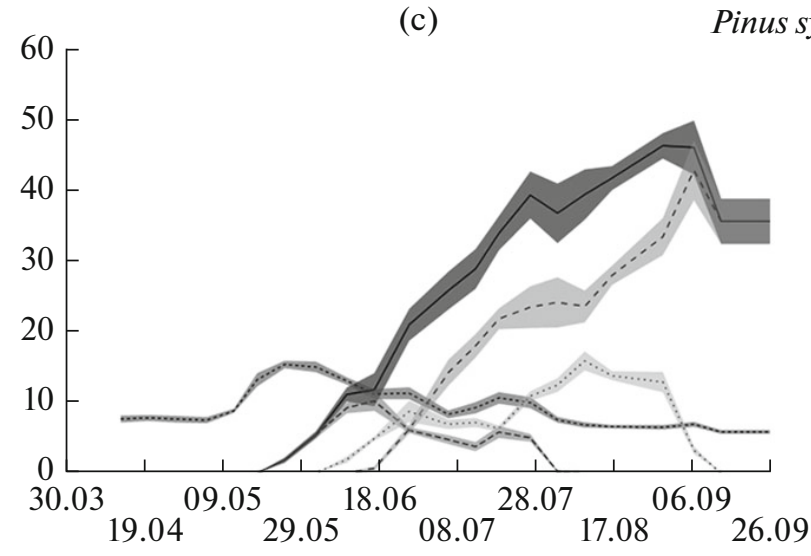

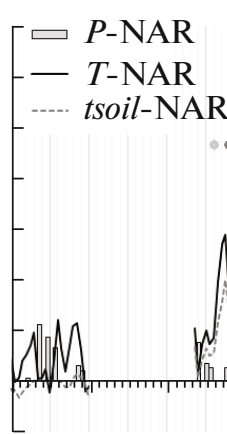

Amount of precipitation, $\mathrm{mm}$

(d) 35

$-30$ $-25$ $-20$ $-15$ 10 5 0 Number of cells sibirica

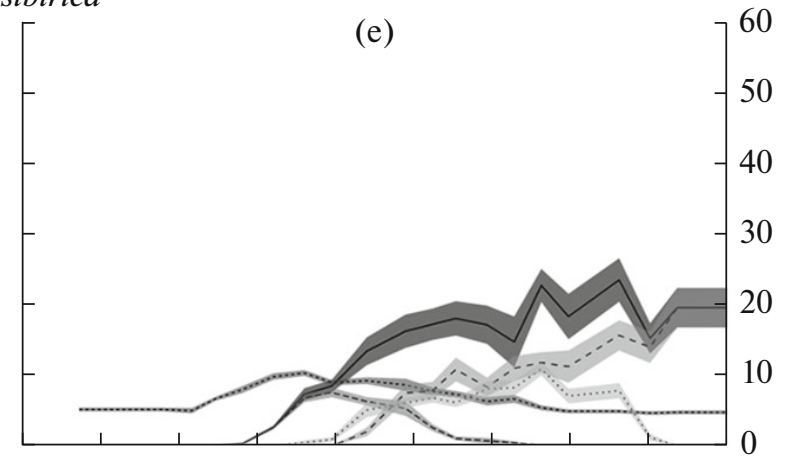

Calendar day of the year

Fig. 1. Daily changes in air temperature $(T)$, soil surface temperature $(t$ soil $)$, and precipitation $(P)$ according to the data of local weather stations in Laletino (LAL (a)) and Narym (NAR (b)) sites, the period from April 23 to May 14 is not included in the weather data). The circles denote phases of larch needle opening: the light-gray circle denotes budding, the gray circle denotes the beginning of needle opening, and the black circle denotes full opening. The averaged (tree number/species/site) number of cells $( \pm$ standard error) in different zones of an tree ring of Siberian larch $(c, d)$ and Scots pine $(e, f)$ throughout the growing season: (1) cambial zone, (2) cell extension zone, (3) zone of cell-wall initial lignification, (4) zone of mature tracheids, $2+3+4$, total number of xylem cells.

The emergence of cells in the initial lignification zone and cell-wall thickening were recorded for all studied species in June 10 (see Table 1). The last cells in this zone were recorded one week earlier for larch than for pine in the LAL site (August 30 and September 7, respectively) and in September 7 for larch and September 14 for pine in the NAR site.
Mature tracheids with the fully formed secondary cell wall in pine earlywood appeared on June 17 in the LAL site and was synchronous (June 26) for trees of different species in the NAR site and for larch from the LAL site (see Table 1). The tree ring was fully formed in September 7 in larch and one week later in pine in the LAL site and on September 14 in larch and Sep- 
Table 1. Duration of different phases of tree-ring formation in Siberian larch and Scots pine in 2012

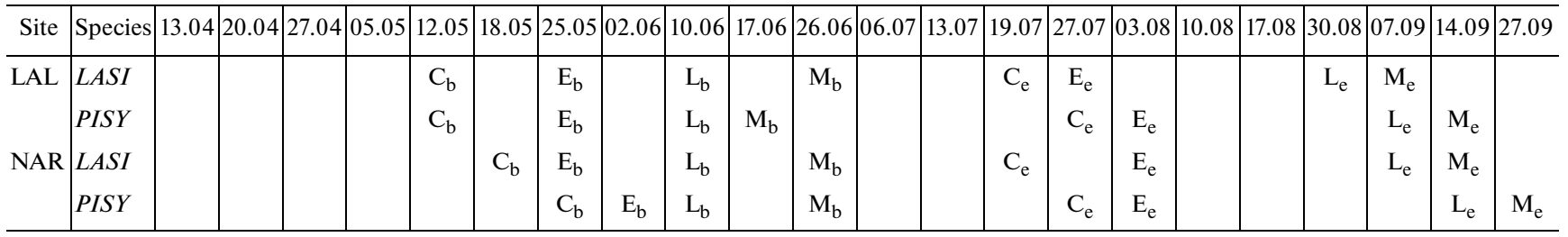

LAL, Laletino; NAR, Narym; LASI, Siberian larch, PISY, Scots pine; $\mathrm{C}_{\mathrm{b}}$ and $\mathrm{C}_{\mathrm{e}}$, the beginning and end of cambial activity; $\mathrm{E}_{\mathrm{b}}$ and $\mathrm{E}_{\mathrm{e}}$, the beginning and end of the tracheid extension phase; $L_{b}$ and $L_{e}$, the beginning and end of the cell-wall lignification phase; $M_{b}$ and $\mathrm{M}_{\mathrm{e}}$, the beginning and end of the emergence of mature tracheids in xylem.

Table 2. Arithmetic mean values of parameters of Siberian larch and Scots pine tracheids formed in 2012

\begin{tabular}{|c|c|c|c|c|c|c|c|}
\hline \multirow{2}{*}{ Site } & \multirow{2}{*}{ Species } & \multirow{2}{*}{$\mathrm{TRW}, \mu \mathrm{m}$} & \multirow{2}{*}{$\begin{array}{c}\text { Number } \\
\text { of cells in a row }\end{array}$} & LD & $\mathrm{D}$ & CWT & \multirow{2}{*}{ EW/LW, \% } \\
\hline & & & & \multicolumn{3}{|c|}{$\mu \mathrm{m}$} & \\
\hline \multirow[t]{2}{*}{ LAL } & $L A S I$ & 819 & 24 & 22 & 34 & 6.1 & $45 / 55$ \\
\hline & PISY & 1022 & 33 & 23 & 31 & 4.0 & $68 / 32$ \\
\hline \multirow[t]{2}{*}{ NAR } & $L A S I$ & 571 & 17 & 23 & 34 & 5.5 & $56 / 44$ \\
\hline & PISY & 1026 & 34 & 24 & 31 & 3.5 & $72 / 28$ \\
\hline
\end{tabular}

LAL, Laletino; NAR, Narym; LASI, Siberian larch; PISY, Scots pine; TRW, tree-ring width; LD, radial lumen size; D, radial tracheid size; CWT, cell-wall thickness; EW/LW, early- and latewood ratio.

tember 27 in pine in the NAR site. Despite the location of the study sites along the altitudinal transect and related differences in the temperature regime, the length of the growing season (from the activation of cambium to the completion of lignification of cell walls of latewood tracheids) was the same for the lowmountain (LAL) and mid-mountain (NAR) sites, being 118 and 125 days for larch and pine trees, respectively.

During the growing season of 2012, relatively wide rings (over $1 \mathrm{~mm}$ ) were formed by pine trees in the two studiy sites (Table 2). Since the correlation between tree-ring width and number of cells forming it is high, the maximum number of cells (56) was also recorded in this species. The average number of tracheids formed per tree ring was 33 for four pine trees. However, the parameters of tracheids (cell-wall thickness and radial cell size) differed in trees from different sites not only in the average values for a ring (Table 2, Fig. 2) but also separately for the earlywood $\left(D_{\text {ew }}=35.6\right.$ and $37.0 \mu \mathrm{m}, \mathrm{CWT}_{\mathrm{ew}}=3.3$ and $\left.3.0 \mu \mathrm{m}\right)$ and latewood $\left(D_{\mathrm{lw}}=20.2\right.$ and $17.3 \mu \mathrm{m}, \mathrm{CWT}_{\mathrm{lw}}=5.6$ and $\left.4.8 \mu \mathrm{m}\right)$ in LAL and NAR, respectively, which, in turn, influenced the width of each zone.

The minimum tree-ring width was recorded for larch trees in the Narym site. It was $20 \%$ lower than that in the Laletino site, which is determined by the size of tracheids of earlywood $\left(D_{\mathrm{ew}}=52.5\right.$ and $47.3 \mu \mathrm{m}$, $\mathrm{CWT}_{\mathrm{ew}}=3.4$ and $\left.3.5 \mu \mathrm{m}\right)$ and latewood $\left(D_{\mathrm{lw}}=20.7\right.$ and $19.7 \mu \mathrm{m}, \mathrm{CWT}_{\mathrm{lw}}=8.1$ and $\left.7.6 \mu \mathrm{m}\right)$ for LAL and NAR, respectively. At the same time, the percentage of earlywood was higher for larch from the Narym site (56\%) than from the Laletino site (45\%).

\section{DISCUSSION}

It was previously shown $[14,15]$ that the growth of Scots pine in the study area was determined by spring temperatures $(R=0.30-0.42, p<0.05)$ for the period from 1947 to 2011, while in Siberian larch it was largely determined by June temperature in this period $(R=$ $0.33, p<0.05$ ). The authors explain such differences by the fact that physiologically active processes (water conduction, photosynthesis, etc.) can start at different times for pine and larch, since the latter requires the annual formation of new photosynthetic apparatus. However, according to our data, the cambial activity itself begins almost simultaneously in both species (Laletino site) or one week later in pine than in larch (Narym site). This is in line with the results of research that indicate earlier dates of the beginning of phenological stages of needle development in larch than in pine [12]. This phenomenon may be determined not only by the presence or absence of the photosynthetic apparatus in trees but also by the redistribution of reserve assimilates within the plant during the initiation of certain processes [16]. Precipitation amount significantly influences the pine growth in June $(R=$ $0.30, p<0.05)$, while larch is not characterized by a significant correlation between tree-ring width and precipitation.

The influence of soil temperature on the beginning of cambial activity and growth of woody plants is complex [17-19], although the rising of air temperature leads to the corresponding increase in soil temperature. The lower threshold of this parameter is generally in the range of $3-5^{\circ} \mathrm{C}[20]$; at the same time, the probability of the beginning of the cambial activity of 
(a)

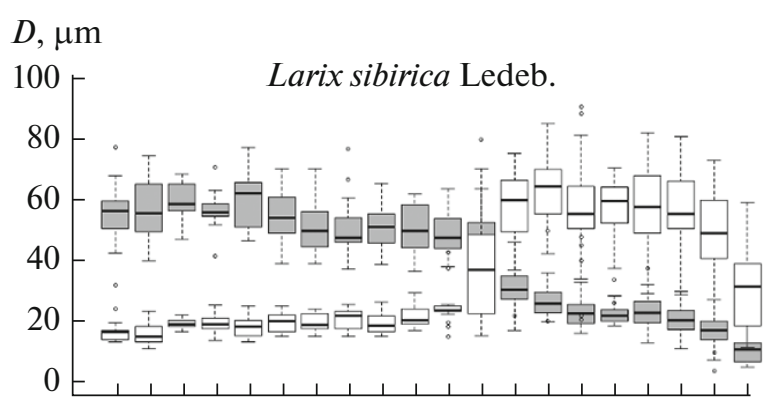

$C W T, \mu \mathrm{m}$

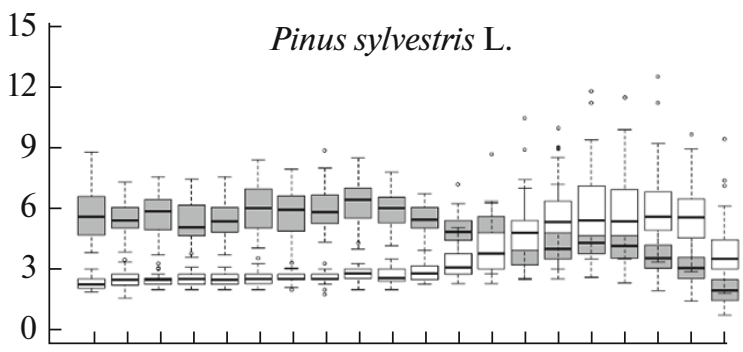

(b)

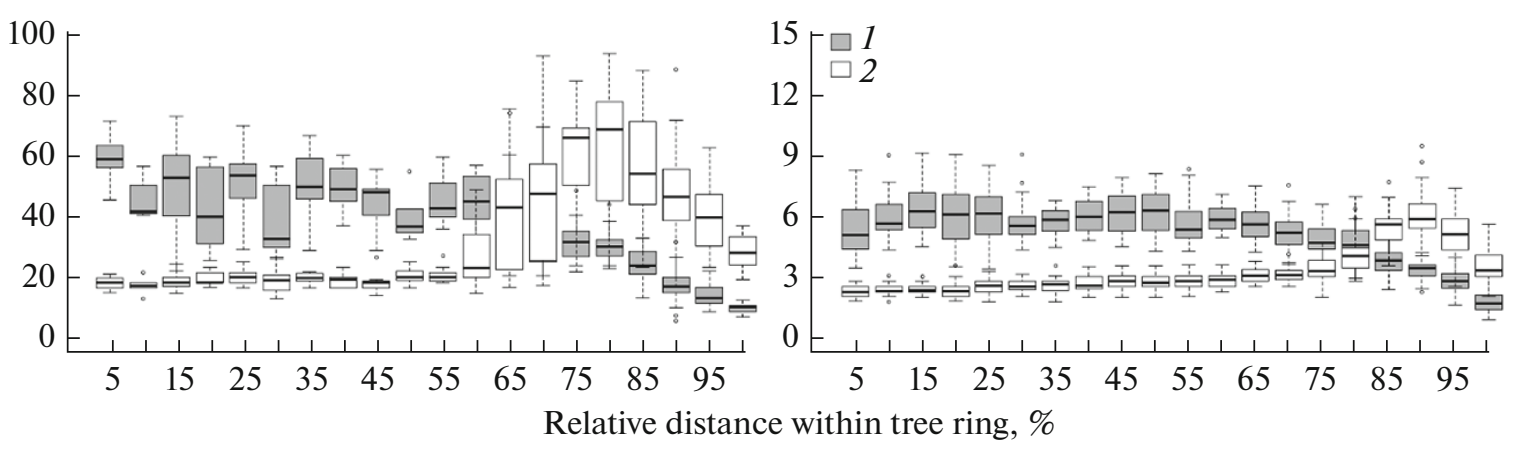

Fig. 2. Boxplot of changes in the radial size of tracheids (1) and cell-wall thickness (2) within larch and pine tree rings formed in 2012 with 5\% step of the relative distance: (a) Laletino site, (b) Narym site. The line inside the box shows the median, the size of the box is determined by the lower and upper quartiles ( 25 and $75 \%$ of the sample size, respectively), the whiskers are the minimum and maximum sample values, the points beyond the range are outliers.

coniferous tree species in Canada was calculated using direct measurements at minimum, moderate, and maximum soil temperatures of $0.2-4.5^{\circ} \mathrm{C}, 2.6-7.5^{\circ} \mathrm{C}$, and $8.3-12.6^{\circ} \mathrm{C}$, respectively, at a depth of $15 \mathrm{~cm}$ [18]. The data that we obtained for the LAL and NAR sites (where the daily average temperature of the soil surface was 3.8 and $4.7^{\circ} \mathrm{C}$, respectively, for the 10-day period before the beginning of the cambial activity and the soil temperature at a depth of $20 \mathrm{~cm}$ was $0.6^{\circ} \mathrm{C}$ in the Narym site in this period) were similar to the previously published results of research [18]. The data on the beginning of growing season in pine and larch at an average air temperature of 7.9 and $6.5^{\circ} \mathrm{C}$ for the 10 -day period in the Laletino and Narym sites are also consistent with the previously published data for boreal trees $[18,21]$, according to which the cambial activity begins to be observed when mean daily temperatures reach $6-8^{\circ} \mathrm{C}$.

It was previously found that the delay in the beginning of cambial activity in European larch along the altitudinal transect in the Alps was 3-4 days per each $100 \mathrm{~m}$ a.s.l. [11]. We obtined similar results for pine trees, when the beginning of the growing season was recorded 13 days later for the high-mountain site than for the low-mountain one. The delay for larch was only 6 days.
According to several studies [22-24], air temperature indirectly influences the reactivation of cambial tissues through the activation and transfer of auxin within the stem; in addition, low spring temperatures may slow down both its biosynthesis and transport. Apical meristems, including buds, developing needles, and shoots, serve as sources of auxin $[25,26]$; therefore, the coordination of the needle phenology with the beginning of xylogenesis is of particular interest $[27,28]$. Despite the obvious relationship between these two processes, the previous results of studies contradict each other. The study of European larch on the altitudinal transect in the Swiss Alps [11] showed that the radial growth of the trees started 3-4 weeks after needle opening, while conifers in Italy and Canada had a different sequence [27, 29]. Our research recorded the division of cambial cells of larch in the Laletino site one week before the onset of the opening of its needles [30], while these two phases coincided for larch trees from the Narym site (see Figs. 1b, 1e). On the whole, the intervals between phases of larch needle opening (budding, the onset of needle extension, and full needle extension) was shorter for the LAL site (2 days) than for the NAR site (4 days).

It should be noted that the previously published data on the limitation of tree growth by air temperature at the end of the growing period, i.e., when it falls to the mean daily values of $8-9^{\circ} \mathrm{C}$ [27], are relevant only 
for pine from the Narym site. The mean temperature was still $12-13^{\circ} \mathrm{C}$ immediately prior to the end of the growing season of larch from both sites and of pine from the Laletino site (when all cells were completely lignified).

Since the main limiting factor of tree growth in the southern taiga zone is air temperature, it is rather difficult to estimate the effect of the precipitation amount on the beginning and duration of cambial activity, as well as on processes of tree-ring formation. The results of research can be reliable only after further monitoring of the seasonal growth of tree rings and accumulation of observation data for several years (or growing seasons).

Despite the well-known species-specific features of the variability in the radial size of the lumen and cell-wall thickness, when pine tracheids have smaller cell size in earlywood and, at the same time, provides a broader transitional zone, while there is actually almost no transitional zone between early- and latewood for larch, the intraseasonal dynamics of anatomical parameters of the xylem for the same species along the altitudinal transect is poorly studied. Thus, the main differences between trees from different sites in both pine and larch were observed in the earlywoodto-latewood ratio, which were determined by changes in cell-wall thickness at relatively similar lumen size (see Table 2, Fig. 2). The wider cell wall of tracheids and the general latewood width were characteristic of trees in the LAL site. Using the previously obtained data on the effect of climate conditions on the radial growth of the study species $[14,15]$ and based on the fact that the period from May to August was $3{ }^{\circ} \mathrm{C}$ warmer and $42 \%$ drier in 2012 than the average for 1947-2016, one can assume that the radial growth of pine and larch trees and anatomical structure of their tree rings under optimal conditions will significantly differ from tree rings formed in 2012.

Therefore, the results of this study confirm the influence of air and soil temperature on the beginning of xylogenesis in Scots pine and Siberian larch: cambial cells started to divide at relatively low temperatures in the mid-mountain site, compared to the lowmountain site. The end of the cambial activity coincides with the period of maximum air temperatures. The revealed correlations and climate data at the beginning and end of the growing season can be further used as input parameters for Vaganov-Shashkin simulation model [2] and will make it possible to achieve the biologically determined consistency between initial tree-ring chronologies and simulation curves. Despite differences in the duration of cambial activity (by up to two weeks), the general length of the growing season was similar for both sites, being 118 days for larch and 125 days for pine. The data on the anatomical parameters of tracheids of the studied species confirm both the species specificity and the effect of site conditions on the growth of Scots pine and Siberian larch along the altitudinal transect.

\section{FUNDING}

This study was supported by the Russian Foundation for Basic Research, project no. 17-04-00610-a).

\section{COMPLIANCE WITH ETHICAL STANDARDS}

The authors declare that they have no conflict of interest. This article does not contain any studies involving animals or human participants performed by any of the authors.

\section{REFERENCES}

1. Climate Change 2013: The Physical Science Basis. Contribution of Working Group I to the Fifth Assessment Report of the Intergovernmental Panel on Climate Change, Stocker, T.F., Qin, D., Plattner, G.-K., et al., Eds., Cambridge, UK: Cambridge Univ. Press, 2013.

2. Vaganov, E.A. and Shashkin, A.V., Rost $i$ struktura godichnykh kolets khvoinykh (Tree Ring Growth and Structure in Conifers), Novosibirsk: Nauka, 2000.

3. Rossi, S., Anfodillo, T., Čufar, K., et al., Pattern of xylem phenology in conifers of cold ecosystems at the Northern Hemisphere, Glob. Change Biol., 2016, vol. 22, pp. 3804-3813. https://doi.org/10.1111/gcb.13317

4. Sviderskaya, I.V., Sukhovol'skii, V.G., Radosteva, E.Yu., and Kirdyanov, A.V., Model estimation of optimal ratio between cell wall thickness and lumen size for the tracheids of conifers, J. Sib. Fed. Univ., Biol., 2011, vol. 4, no. 2, pp. 183-196.

5. Fonti, P. and Jansen, S., Xylem plasticity in response to climate, New Phytol., 2012, vol. 195, no. 4, pp. 734-736. https://doi.org/10.1111/j.1469-8137.2012.04252.x

6. Antonova, G.F. and Stasova, V.V., Effects of environmental factors on wood formation in Scots pine stems, Trees, 1993, vol. 7, pp. 214-219.

https://doi.org/10.1007/BF00202076

7. Deslauriers, A. and Morin, H., Intra-annual tracheid production in balsam fir stems and the effect of meteorological variables, Trees, 2005 , vol. 19, no. 4, pp. 402408.

https://doi.org/10.1007/s00468-004-0398-8

8. Eilmann, B., Zweifel, R., Buchmann, N., et al., Drought-induced adaptation of the xylem in Scots pine and pubescent oak, Tree Physiol., 2009, vol. 29, pp. $1011-1020$.

https://doi.org/10.1093/treephys/tpp035

9. Bryukhanova, M.V., Kirdyanov, A.V., Prokushkin, A.S., and Silkin, P.P., Specific features of xylogenesis in Dahurian larch, Larix gmelinii (Rupr.) Rupr., growing on permafrost soils in Middle Siberia, Russ. J. Ecol., 2013, vol. 44, no. 5, pp. 361-366. https://doi.org/10.1134/S1067413613050044

10. Körner, C., The use of "altitude" in ecological research, Trends Ecol. Evol., 2007, vol. 22, pp. 569-574.

https://doi.org/10.1016/j.tree.2007.09.006 
11. Moser, L., Fonti, P., Büntgen, U., et al., Timing and duration of European larch growing season along altitudinal gradients in the Swiss Alps, Tree Physiol., 2010, vol. 30 , pp. $225-233$. https://doi.org/10.1093/treephys/tpp108

12. Ovchinnikova, T.M., Fomina, V.A., Andreeva, E.B., et al., Analysis of changes in the timing of seasonal phenomena in trees of the Stolby Nature Reserve as related to climatic factors, Khvoinye Boreal. Zony, 2011, nos. 1-2, pp. 47-54.

13. Denne, M.P., Definition of latewood according to Mork (1928), IAWA Bull., 1989, vol. 10, pp. 59-62. https://doi.org/10.1163/22941932-90001112

14. Knorre, A.A. and Konurbaeva, R.U., Impact of recreation on the formation of radial increment in Scots pine (Pinus sylvestris L.) in the Stolby Nature Reserve, in Nauchnye issledovaniya $v$ zapovednikakh $i$ natsional'nykh parkakh Yuzhnoi Sibiri (Scientific Research in Nature Reserves and National Parks of Southern Siberia), vol. 2, Novosibirsk: Sib. Otd. Ross. Akad. Nauk, 2012, pp. 160-165.

15. Konurbaeva, R.U., Responses of main tree species to climate change in the mountain taiga belt of the Eastern Sayan, M. Sci. Thesis, Krasnoyarsk: Sib. Fed. Univ., 2012.

16. Chapin, F.S., Schulze, E., and Mooney, H.A., The ecology and economics of storage in plants, Ann. Rev. Ecol. Syst., 1990, vol. 21, pp. 423-447. https://doi.org/10.1146/annurev.es.21.110190.002231

17. Landhausser, S.M., Desrochers, A., and Lieffers, V.J., A comparison of growth and physiology in Picea glauca and Populus tremuloides at different soil temperatures, Can. J. For. Res., 2001, vol. 31, no. 11, pp. 1922-1929. https://doi.org/10.1139/x01-129

18. Rossi, S., Deslauriers, A., Anfodillo, T., and Carraro, V., Evidence of threshold temperatures for xylogenesis in conifers at high altitudes, Oecologia, 2007, vol. 152, pp. $1-12$. https://doi.org/10.1007/s00442-006-0625-7

19. Lupi, C., Morin, H., Deslauriers, A., and Rossi, S., Xylogenesis in black spruce: Does soil temperature matter?, Tree Physiol., 2012, vol. 32, pp. 74-82. https://doi.org/10.1093/treephys/tpr132

20. Körner, C., Alpine Plant Life: Functional Plant Ecology of High Mountain Ecosystems, Berlin: Springer-Verlag, 2003. https://doi.org/10.1007/978-3-642-18970-8

21. Rossi, S., Deslauriers, A., Gričar, J., et al., Critical temperatures for xylogenesis in conifers of cold cli- mates, Glob. Ecol. Biogeogr., 2008, vol. 17, pp. 696-707. https://doi.org/10.1111/j.1466-8238.2008.00417.x

22. Oribe, Y. and Kubo, T., Effect of heat on cambial reactivation during winter dormancy in evergreen and deciduous conifers, Tree Physiol., 1997, vol. 17, pp. 81-87. https://doi.org/10.1093/treephys/17.2.81

23. Uggla, C., Magel, E., Moritz, T., and Sundberg, B., Function and dynamics of auxin and carbohydrates during earlywood/latewood transition in Scots pine, Plant Physiol., 2001, vol. 125, no. 4, pp. 2029-2039. https://doi.org/10.1104/pp.125.4.2029

24. Oribe, Y., Funada, R., and Kubo, T., Relationships between cambial activity, cell differentiation and the localization of starch in storage tissues around the cambium in locally heated stems of Abies sachalinensis (Schmidt) Masters, Trees: Struct. Funct., 2003, vol. 17, pp. 185-192.

https://doi.org/10.1007/s00468-002-0231-1

25. Savidge, R.A., Auxin and ethylene regulation of diameter growth in trees, Tree Physiol., 1988, vol. 4, no. 4, pp. 401-414.

https://doi.org/10.1093/treephys/4.4.401

26. Sundberg, B. and Uggla, C., Origin and dynamics of indoleacetic acid under polar transport in Pinus sylvestris, Physiol. Plant., 1998, vol. 104, no. 1, pp. 22-29. https://doi.org/10.1034/j.1399-3054.1998.1040104.X

27. Rossi, S., Rathgeber, C.B.K., and Deslauriers, A., Comparing needle and shoot phenology with xylem development on three conifer species in Italy, Ann. For. Sci., 2009, vol. 66, no. 2, p. 206. https://doi.org/10.1051/forest/2008088

28. Swidrak, I., Schuster, R., and Oberhuber, W., Comparing growth phenology of co-occurring deciduous and evergreen conifers exposed to drought, Flora, 2013, vol. 208, pp. 609-617. https://doi.org/10.1016/j.flora.2013.09.004

29. Zhai, L., Bergeron, Y., Huang, J.G., and Berninger, F., Variation in intra-annual wood formation, and foliage and shoot development of three major Canadian boreal tree species, Am. J. Bot., 2012, vol. 99, no. 5, pp. 827-837. https://doi.org/10.3732/ajb.1100235

30. Dolzhkovaya, N.P., Plant calendar, in Letopis' Prirody gosudarstvennogo prirodnogo zapovednika "Stolby" (Annals of Nature of the Stolby State Nature Reserve), 2012, vol. 70, pp. 61-65.

Translated by D. Zabolotny 